\title{
Primary care pearls to help eliminate tuberculosis in Canada
}

\author{
Amaratunga $\mathrm{KR}^{1,2^{*}}$, Alvarez $\mathrm{GG}^{3,4}$
}

\begin{abstract}
Although Canada has a low incidence of tuberculosis (TB), certain populations, including the foreign-born and Canadian-born Indigenous peoples, continue to be disproportionately represented among reported cases. The overall incidence rates of active TB in Canada have not significantly changed in the past decade and work still needs to be done to reach TB elimination goals set by the World Health Organization (WHO). In trying to achieve TB elimination in Canada, primary care clinicians, with the support of public health professionals and TB experts, can help by focusing on 1) targeted screening and treatment of latent TB infection (LTBI) and 2) timely diagnosis and referral of active TB disease. The following article focuses on some key primary care considerations to keep in mind in day-to-day patient care. To help conduct targeted screening and treatment for LTBI, several key populations, including immigrants from high TB burden countries, Indigenous peoples and several other at-risk groups, are outlined. Reactivation of LTBI plays a significant role in TB burden and is likely an area of major potential impact in achieving TB elimination. Advancement in LTBI treatment, including short course therapy, is also described. In addition, to help make a timely diagnosis of active TB, several key risk factors, including several co-morbidities which increase the risk of developing TB disease, can be considered. Being front-line in patient care, keeping in mind some of these key pearls may aid primary care providers to have potential impact on eliminating TB in Canada.
\end{abstract}

\author{
Affiliations \\ ${ }^{1}$ Centre for Communicable \\ Diseases and Infection Control, \\ Public Health Agency of Canada, \\ Ottawa, ON \\ 2University of Ottawa, \\ Department of Medicine, Division \\ of Infectious Diseases, Ottawa, \\ ON \\ ${ }^{3}$ University of Ottawa, \\ Departments of Medicine, \\ Epidemiology and Community \\ Medicine, Divisions of \\ Respirology and Infectious \\ Diseases, Ottawa, ON \\ ${ }^{4}$ Ottawa Hospital Research \\ Institute, Ottawa, ON
}

*Correspondence: kanchana. amaratunga@phac-aspc.gc.ca

Suggested citation: Amaratunga KR, Alvarez GG. Primary care pearls to help eliminate tuberculosis in Canada. Can Comm Dis Rep 2016;42:63-7. https://doi.org/10.14745/ccdr.v42i03a03

\section{Introduction}

In May 2014, the World Health Assembly approved the World Health Organization's (WHO's) post-2015 global strategy to end tuberculosis (TB) by 2035. The ambitious targets included reducing the global incidence of TB to fewer than 100 cases per 1,000,000 population; this would require a $95 \%$ reduction in the number of deaths due to TB and a $90 \%$ reduction in the incidence of TB by 2035, as compared to 2015 (1). For

low-incidence countries, such as Canada, which have already reached a TB incidence of less than 100 per 1,000,000 population, the global strategy has been adapted to provide a framework for TB elimination, defined as less than 1 TB case per $1,000,000$ population by 2050 (1).

Despite being a low-incidence country, there is still work to be done in order to eliminate TB in Canada. Based on The Global Plan to Stop TB 2006-2015 (WHO) (2), Canada's goal was to reach a target incidence of 3.6 per 100,000 population per year by 2015, a target that was reiterated in the 2014 Tuberculosis Prevention and Control in Canada: A Federal Framework for Action (3). Between 2003 and 2013, the reported overall incidence rate of TB disease in Canada ranged from 5.2 cases per 100,000 population to 4.7 cases per 100,000 population, respectively (4). Although the incidence of active TB disease in the overall Canadian population is among the lowest in the world, the rates have not significantly changed in the past decade. Foreign-born and Canadian-born Indigenous populations continue to be disproportionately represented among reported cases. In 2013, the foreign-born population, which represented approximately $22 \%$ of the total Canadian population, accounted for $71 \%$ of reported cases, whereas Canadian-born Indigenous people, who made up $4 \%$ of the total Canadian population, accounted for $19 \%$ of reported cases (4).

The WHO action framework cites several challenges to TB elimination in low-incidence countries, including diminishing clinical and diagnostic expertise, as well as diminishing awareness of TB as a result of the fall in incidence (1). One of the eight outlined priority action areas for these countries include undertaking screening for latent TB infection (LTBI) and active TB among contacts and selected high-risk groups, and providing appropriate treatment (1).

Primary care clinicians provide care for individuals from diverse backgrounds and will inadvertently be caring for populations who are at increased risk for both TB disease and TB infection. As TB incidence rates decline in Canada, the overall level of physician experience with the disease will also decline. Hence, as important as it is for experienced clinicians to manage TB cases, it is just as much a priority to keep referring physicians, including those in primary care, abreast of developments in TB screening and disease management (5). 
Primary care clinicians, with the support of public health professionals and TB experts, have two key roles in Canada's elimination efforts: conducting targeted screening and treatment of LTBI, which prevents reactivation and helps accelerate the decline in TB incidence, and making timely diagnosis of active TB disease, which prevents further transmission and helps maintain the decline in TB incidence.

\section{Targeted screening and treatment for latent TB infection}

Based on recent data presented at the Advisory Council for the Elimination of Tuberculosis (ACET) at the Centers for Disease Control and Prevention in December 2015, the number of TB cases originating from reactivation of LTBI may be even higher than previously thought (6). Advisory Council members determined that targeting LTBI would be an area of biggest potential impact on achieving TB elimination goals; however, it is a daunting task.

Each year approximately 250,000 immigrants and refugees settle in Canada $(7,8)$. As part of the Immigration Medical Examination (IME) conducted on individuals applying for permanent residency and some categories of temporary residency, those aged 11 years and older should have a chest x-ray completed in their country of origin $(8,9)$. Based on the IME history and a physical examination, anyone suspected of having active TB should be referred for further assessment in their country of origin and those diagnosed with active TB must complete their treatment before arriving in Canada (7).

Post-immigration surveillance of selected immigrants considered high risk for developing active TB is also based on certain risk factors found in the IME (7). The goal of the IME is to ensure that migrants with active TB are diagnosed, treated and no longer infectious prior to arriving in Canada; it does not aim to detect or treat LTBI (8). Neither tuberculin skin tests (TST) nor interferon-gamma release assays (IGRA) are routinely done on newcomers to Canada. Mass screening of this entire population is not recommended since it would be logistically impossible and largely ineffective.

The selection of individuals for targeted LTBI screening and treatment is based on their risk of prior exposure to TB and their risk of reactivation, balanced against the likelihood of safe completion of treatment, including the risk of hepatotoxicity (10). Determining which patients may benefit from LTBI screening and treatment may not be straightforward in all circumstances.

Table 1 is based on the most recent Canadian Tuberculosis Standards, 7th Edition, developed by the Canadian Thoracic Society and the Public Health Agency of Canada. It summarizes seven select groups from various at-risk populations that primary care physicians may commonly encounter in their practice and who they should consider for targeted LTBI screening.

A free online tool is available from McGill University (http://www.tstin3d.com/) to help interpret TST or IGRA results by estimating the risk of developing active TB disease using the key risk factors discussed in Table 1 (14). Nevertheless, clinicians must always balance the patient's risk of reactivation and the capacity for ongoing follow-up if screening and treatment are offered. The likelihood of safe completion of treatment, including ongoing monitoring for potential adverse effects, such as hepatotoxicity, while on treatment also needs to be considered (10). If screening is offered and the patient is suspected to have LTBI based on a positive TST or IGRA, active disease must be excluded carefully before initiation of LTBI therapy. Exclusion of active TB disease typically includes a symptom screen, chest $x$-ray and sputum smear and culture.

\section{Advances in treatment for latent TB infection}

Significant progress has been made in improving the lengthy LTBI therapy. A multicentered, multinational randomized control noninferiority trial with approximately 4,000 patients per arm demonstrated that rifapentine and isoniazid (commonly known as $3 \mathrm{HP}$ ) administered once weekly for a total of 12 doses given directly observed was as effective as the current international standard of 9 months (252 doses) of daily isoniazid self-administered for the treatment of LTBI (15).The 3HP regimen also resulted in a higher completion rate. A more recent randomized control trial (RCT) in the pediatric population also evaluated the effectiveness of 3HP therapy. In this study, which included 905 patients between the ages of 2 and 17 years, 3HP was shown to be as effective as isoniazid alone in preventing TB disease in children and also had higher completion rates compared to the standard 9 months of isoniazid (16).

At present, 3HP treatment for LTBI is available in Canada through Health Canada's Special Access Programme only.

\section{Making a timely diagnosis of active TB disease}

Although the rate of TB transmission in the general population in Canada is low, active TB disease and transmission is seen in at-risk groups, including during outbreaks in Indigenous communities and in some aggregate settings (such as shelters, prisons, schools, etc.). Making a timely diagnosis is critical to interrupting transmission and is a main priority in TB control.

The patient's history, including key risk factors, signs and symptoms, and his/her chest x-ray is paramount to the diagnosis of TB disease. Among new Canadians, their countries of origin and the time since arriving in Canada are key. Recent evidence from a large retrospective epidemiological study in Ontario suggests that immigrants from 6 countries (Afghanistan, China, India, Pakistan, the Philippines and Vietnam) accounted for $87 \%$ of active TB cases detected through pre-immigration screening, while those from 10 high-incidence countries accounted for $80 \%$ of active TB cases detected through post-immigration surveillance (7). In addition, this study demonstrated that the category of immigrants was associated with an increased risk of developing active TB disease following their arrival in Canada, with live-in caregivers and refugees at the highest risk (7). The risk of active TB disease reactivation is highest in the first two years following arrival and decreases with every subsequent year (17). In addition, in the medical history it is important to elicit the region of residence and ethnicity of Canadian-born individuals since some regions and populations within Canada, including Canadian-born Indigenous peoples, have higher TB incidence. Other important risk factors are listed in Table 2.

Presence of one or more high or moderate risk factor in a patient with symptoms and an epidemiological risk for TB can greatly increase the probability of a TB diagnosis (18). Signs 
Table 1: Recommendations of the Canadian Thoracic Society for groups for targeted latent TB infection screening

\begin{tabular}{|c|c|}
\hline Group at risk & Group to be screened (age range/limit for screening) \\
\hline $\begin{array}{l}\text { 1. Close contacts } \\
\text { of an active case of } \\
\text { pulmonary TB }\end{array}$ & $\begin{array}{l}\text { As soon as possible after diagnosis of the index case (Any age)Contacts grouped as follows (11): } \\
\text { - High priority: household contacts plus close non-household contacts who are immunologically vulnerable, e.g. children }<5 \\
\text { - Mears } \\
\text { - } \text { - Low priority: casual contacts with lower amounts of exposure } \\
\text { Index case as follows (11): } \\
\text { - Smear-positive cavitary/laryngeal TB: initial contact follow-up includes both high- and medium-priority contacts } \\
\text { - Smear-negative, non-cavitary pulmonary TB: initial contact follow-up of high-priority contacts only }\end{array}$ \\
\hline $\begin{array}{l}\text { 2. Immigrants from } \\
\text { countries with high } \\
\text { TB incidence } 1 \\
\text { (defined as } \geq 30 \\
\text { cases } / 100,000 \\
\text { population for all } \\
\text { forms of active TB } \\
\text { cases) }\end{array}$ & $\begin{array}{l}\text { Fibronodular changes on chest } x \text {-ray (usually in the context of post-landing surveillance) [Any age] } \\
\text { All children and adolescents as soon as possible after arrival (Up to age } 20 \text { years) } \\
\text { Refugees ( } 20-50 \text { years) } \\
\text { Immigrants and refugees with underlying medical comorbidities with the following risk of TB reactivation²: } \\
\text { - High risk (Any age) } \\
\text { - Moderate risk (Up to } 65 \text { years) } \\
\text { - Slightly increased risk (Up to } 50 \text { years) }\end{array}$ \\
\hline $\begin{array}{l}\text { 3. Indigenous } \\
\text { peoples }^{3}\end{array}$ & $\begin{array}{l}\text { Varies by TB risk in the community (12) } \\
\text { Follow up of close contacts of an active case of pulmonary TB (as above) [Any age] } \\
\text { In the presence of underlying medical comorbidities with the following risk of TB reactivation²: } \\
\text { - High risk (Any age) } \\
\text { - Moderate risk (Up to } 65 \text { years) } \\
\text { - Slightly increased risk (Up to } 50 \text { years) }\end{array}$ \\
\hline $\begin{array}{l}\text { 4. Injection drug } \\
\text { user OR the } \\
\text { homeless }\end{array}$ & $\begin{array}{l}\text { In the presence of underlying medical comorbidities with the following risk of TB reactivation²: } \\
\text { - High risk }{ }^{4} \text { (Any age) } \\
\text { - Moderate risk (Up to } 65 \text { years) } \\
\text { - Slightly increased risk (Up to } 50 \text { years) }\end{array}$ \\
\hline $\begin{array}{l}\text { 5. Medical } \\
\text { comorbidities } \\
\text { (including HIV) }\end{array}$ & $\begin{array}{l}\text { All individuals, regardless of prior TB exposure, should be considered for screening if they have certain medical comorbidities } \\
\text { that increase risk of TB reactivation²: } \\
\text { - High risk (Any age) } \\
\text { - Moderate risk (Up to } 65 \text { years) } \\
\text { - Slightly increased risk (Up to } 50 \text { years) }\end{array}$ \\
\hline $\begin{array}{l}\text { 6. Travellers to } \\
\text { countries with high } \\
\text { TB incidence }\end{array}$ & $\begin{array}{l}\geq 1 \text { month of travel with very high-risk contact, particularly direct patient contact in a hospital or indoor setting, but possibly } \\
\text { including work in prisons, homeless shelters, refugee camps or inner city slums (Up to } 50 \text { years if single post-travel TST) } \\
\geq 3 \text { months of travel to TB incidence country }>400 / 100,000 \text { population }{ }^{1} \text { (Any age if documented TST conversion) } \\
\geq 6 \text { months of travel to TB incidence country } 200-399 / 100,0001 \text { population }{ }^{1} \text { (Any age if documented TST conversion) } \\
\geq 12 \text { months of travel to TB incidence country } 100-199 / 100,000 \text { population }{ }^{1} \text { (Any age if documented TST conversion) }\end{array}$ \\
\hline $\begin{array}{l}\text { 7. Residents of } \\
\text { long-term care } \\
\text { facilities }\end{array}$ & $\begin{array}{l}\text { Baseline posterior-anterior and lateral chest x-ray on admission for those from at-risk population6 (>65 years) [13] } \\
\text { Baseline two-step TST upon admission for at-risk population }{ }^{6} \text { ( } \leq 65 \text { years) [13] } \\
\text { Annual TST not necessary (13) } \\
\text { TST no longer recommended as a primary assessment tool in the contact follow-up of elderly residents in long-term care; } \\
\text { focus should be on early detection of secondary active cases (13) }\end{array}$ \\
\hline
\end{tabular}

Source: Can Respir J. 2013;20(SA):119A-128A.(8)

Abbreviations: HIV, human immunodeficiency virus; TB, tuberculosis; TST, tuberculin skin test

'See http://data.worldbank.org/indicator/SH.TBS.INCD for the most recent TB rates by country.

${ }^{2}$ Risk of reactivation for different medical comorbidities (by risk category) outlined in Table 2 below

${ }^{3}$ The TB Standards provide multifactorial considerations when considering TB in this population

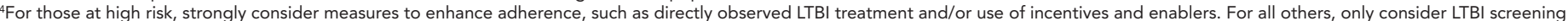
and treatment provided treatment completion and adequate follow-up for hepatotoxicity can be achieved

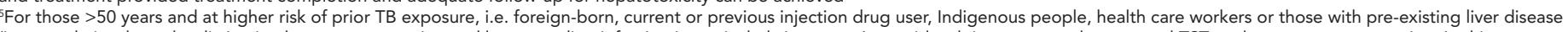
(i.e. people in whom the distinction between conversion and long-standing infection is particularly important), consider doing a pre- and post-travel TST to detect recent conversion. In this case,

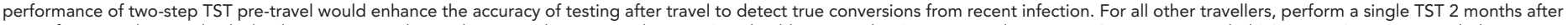
return from travel. For individuals who are expected to undergo serial or repeated testing (e.g. health care workers), a pre-travel two-step TST is recommended (IGRA is NOT recommended).

${ }^{6}$ At-risk populations: history of active TB; staff and residents of homeless shelters; urban poor; staff and inmates of correctional facilities and previously incarcerated people; injection drug users;

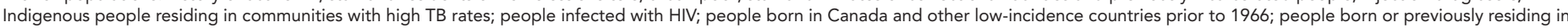
high-incidence countries; people with high medical risk factors listed in Table 2; health care workers serving at-risk groups (11).

Note: For Groups 1, 2 \& 5, conditional recommendation, based on moderate to weak evidence. For Groups 4 \& 6, conditional recommendation, based on weak evidence. 
and symptoms of TB disease include weight loss, fevers, chronic cough, night sweats and hemoptysis. Although many of these symptoms are common to other diseases that present in low-incidence countries, they should be used in the context of a history that increases the pre-test probability of TB disease. In a recent review, several important clinical pearls are presented addressing seven clinical questions, six related to patient history and one related to laboratory/radiographic workup to help make

Table 2: Risk factors for the development of active tuberculosis among individuals presumed to be infected with Mycobacterium tuberculosis

\begin{tabular}{|c|c|c|}
\hline Level of risk & Risk factor & $\begin{array}{l}\text { Estimated risk for } \\
\mathrm{TB}^{1}\end{array}$ \\
\hline \multirow[t]{8}{*}{$\mathrm{HIGH}$} & AIDS & $110-170$ \\
\hline & HIV & $50-110$ \\
\hline & $\begin{array}{l}\text { Transplantation (related to } \\
\text { immunosuppressive } \\
\text { therapy) }\end{array}$ & $20-74$ \\
\hline & Silicosis & 30 \\
\hline & $\begin{array}{l}\text { Chronic renal failure } \\
\text { requiring hemodialysis }\end{array}$ & $7-50$ \\
\hline & $\begin{array}{l}\text { Carcinoma of head and } \\
\text { neck }\end{array}$ & 11.6 \\
\hline & $\begin{array}{l}\text { Recent TB infection } \\
(\leq 2 \text { years) }\end{array}$ & 15.0 \\
\hline & $\begin{array}{l}\text { Abnormal chest } \\
\text { x-ray - fibronodular disease }\end{array}$ & $6-19$ \\
\hline \multirow[t]{4}{*}{ MODERATE } & $\begin{array}{l}\text { Tumour necrosis factor } \\
\text { (TNF) alpha inhibitors }\end{array}$ & $1.5-5.8$ \\
\hline & Diabetes mellitus (all types) & $2-3.6$ \\
\hline & $\begin{array}{l}\text { Treatment with } \\
\text { glucocorticoids } \\
\text { ( } \geq 15 \mathrm{mg} / \text { day prednisone) }\end{array}$ & 4.9 \\
\hline & $\begin{array}{l}\text { Young age when infected } \\
\text { (0-4 years) }\end{array}$ & $2.2-5$ \\
\hline \multirow[t]{4}{*}{$\begin{array}{l}\text { SLIGHTLY } \\
\text { INCREASED }\end{array}$} & $\begin{array}{l}\text { Heavy alcohol consumption } \\
\text { ( } \geq 3 \text { drinks/day) }\end{array}$ & $3-4$ \\
\hline & $\begin{array}{l}\text { Underweight ( }<90 \% \\
\text { ideal body weight; for most } \\
\text { people, this is a body mass } \\
\text { index } \leq 20 \mathrm{~kg} / \mathrm{m} 2 \text { ) }\end{array}$ & $2-3$ \\
\hline & $\begin{array}{l}\text { Cigarette smoker (1 pack/ } \\
\text { day) }\end{array}$ & $1.8-3.5$ \\
\hline & $\begin{array}{l}\text { Abnormal chest } \\
\text { x-ray - granuloma }\end{array}$ & 2 \\
\hline
\end{tabular}

Adapted from Can Respir J. 2013; 20(Suppl A):45A (10)

Abbreviations: AIDS, acquired immunodeficiency syndrome; HIV, human immunodeficiency virus Relative to people with no known risk factor

a timely diagnosis of pulmonary TB (18).

The chest x-ray, including the classic adult presentation of upper lobe disease with fibronodular disease, cavities or pleural effusions, is often quite helpful in the diagnosis. However, it is important to note that active TB disease can still be present even if the chest x-ray is normal. It is paramount that all people who are suspected of having active TB disease have sputa sent for smear and culture to confirm the diagnosis and obtain susceptibilities. If a diagnosis of active TB is made, primary care practitioners should notify and collaborate with local public health services. Local public health professionals play a vital role in providing support in TB case management, including conducting contact investigations, providing TB medications and directly observed therapy for active cases. In addition, primary care providers should consider referring patients, especially complicated cases, to TB clinicians or specialized clinics for consultation and support with ongoing management.

\section{Conclusion}

Although Canada is a low-incidence country, the incidence rates of active TB disease in the overall population have not significantly changed in the past decade and striking disparity still exists in certain at-risk populations. When striving for TB elimination, primary care clinicians can be a part of the solution by focusing on 1) targeted screening and treatment of LTBI, and 2) timely identification and referral of active TB disease. Primary care providers, with their wide range of practices, inadvertently care for those populations who are at increased risk for both TB disease and TB infection and so play a vital role in the nation's overall TB elimination goals. Hence, they must remain up-to-date on TB prevention and control approaches and should consider the clinical pearls and resources described in this article in their day-to-day practice when caring for at-risk patients.

\section{Conflict of interest}

None.

\section{References}

1. World Health Organization. Towards tuberculosis elimination: an action framework for low-incidence countries. Geneva (CH): WHO; 2014. http://apps.who. int/iris/bitstream/10665/132231/1/9789241507707_eng. pdf?ua $=1$.

2. Stop TB Partnership. The Global Plan to Stop TB 2006-2015. Geneva (CH): World Health Organization; 2006. http://www. stoptb.org/assets/documents/global/plan/globalplanfinal. pdf.

3. Public Health Agency of Canada. Tuberculosis prevention and control in Canada: a federal framework for action. Ottawa (ON): The Agency; 2014. http://www.phac-aspc. gc.ca/tbpc-latb/pubs/tpc-pct/assets/pdf/tpc-pcta-eng.pdf.

4. Public Health Agency of Canada. Tuberculosis in Canada 2013 - Pre-release. Ottawa (ON): The Agency; 2015.

5. Long R. Physician experience, public health and the management of tuberculosis. CMAJ. 2006;175(7):759.

6. Centers for Disease Control and Prevention (CDC). Advisory Council for the Elimination of Tuberculosis (ACET) Meeting; 2015 Dec 15-16; Atlanta, GA. http://www.cdc.gov/maso/ facm/facmACET.htm.

7. Khan K, Hirji MM, Miniota J, Hu W, Wang J, Gardam M, et al. Domestic impact of tuberculosis screening among new immigrants to Ontario, Canada. CMAJ. 2015;187(16):E47381. 
8. Greenway C, Khan K, Schwartzman K. Tuberculosis surveillance and screening in selected high-risk populations. In: Menzies D, ed. The Canadian tuberculosis standards, 7th Edition. Can Respir J. 2013; 20(Suppl A):119A-28A. http:// tbevidence.org/wp-content/uploads/2013/07/Canadian-TBStandards-7th-Ed-2013.pdf.

9. Immigration, Refugees and Citizenship Canada (IRCC). Panel members' handbook 2013. Ottawa(ON): IRCC; 2015. http://www.cic.gc.ca/english/resources/publications/dmphandbook/index.asp.

10. Menzies D, Alvarez GG, Khan K. Treatment of latent tuberculosis infection. In: Menzies D, ed. The Canadian tuberculosis standards, 7th edition. Can Respir J. 2013;20(Suppl A):44A-53A. http://tbevidence.org/wpcontent/uploads/2013/07/Canadian-TB-Standards-7thEd-2013.pdf.

11. Rea E, Rivest P. Contact follow-up and outbreak management in tuberculosis control. In: Menzies D, ed. The Canadian tuberculosis standards, 7th Edition. Can Respir J. 2013;20(Suppl A):108A-18A. http://tbevidence.org/ wp-content/uploads/2013/07/Canadian-TB-Standards-7thEd-2013.pdf.

12. Alvarez GG, Orr P, Wobeser WL, Cook V, Long R. Tuberculosis prevention and care in First Nations, Inuit and Métis people. In: Menzies D, ed. The Canadian tuberculosis standards 7th Edition. Can Respir J. 2013;20(Suppl A):129A35A. http://tbevidence.org/wp-content/uploads/2013/07/ Canadian-TB-Standards-7th-Ed-2013.pdf.
13. Ogunremi T, Menzies D, Embil J. Prevention and control of tuberculosis transmission in health care and other settings. In: Menzies D, ed. The Canadian tuberculosis standards, 7th Edition. Can Respir J 2013;20(Suppl A):136A-51A. http:// tbevidence.org/wp-content/uploads/2013/07/Canadian-TBStandards-7th-Ed-2013.pdf.

14. McGill University. The Online TST/IGRA Interpreter. Version 3.0 http://www.tstin3d.com/.

15. Sterling TR, Villarino ME, Borisov AS, Shang N, Gordin F, Bliven-Sizemore $\mathrm{E}$, et al. Three months of rifapentine and isoniazid for latent tuberculosis infection. N Engl J Med. 2011;365:2155-66.

16. Villarino ME, Scott NA, Weis SE, Weiner M, Conde $M B$, Jones $B$, et al. Treatment for preventing tuberculosis in children and adolescents: a randomized clinical trial of a 3-month, 12-dose regimen of a combination of rifapentine and isoniazid. JAMA Pediatr. 2015;169(3):247-55.

17. Cain KP, Benoit SR, Winston CA, Mac Kenzie WR. Tuberculosis among foreign-born persons in the United States. JAMA. 2008;300(4):405-12.

18. Long R. Making a timely diagnosis of tuberculosis. Can Respir J. 2015;22(6):317-21. 